\title{
THE IMPORTANCE OF BRAND IN CONSUMER BUYING BEHAVIOR AND PRODUCT QUALITY ASSESMENT
}

\author{
Viera Valjaskova ${ }^{1}$, Pavol Kral ${ }^{2}$
}

\begin{abstract}
In order to maintain or increase market share, every company tries to use the most optimal combination of marketing communication tools or marketing mix tools. There are a large number of products placed on the market from a large number of companies that need to distinguish one another from competing companies. The most important tool to differentiate from competitors is the brand of products. The aim of each company is to ensure that their product brand is brought to the attention of customers and that customers associate especially positive associations with its brand(s). We are of the opinion that if the first and then repeated purchase of customers of the same product of a given brand confirms that the product meets the required characteristics and quality they expect from the product, customers will not doubt the quality of the products sold under the brand and will regard it as quality. For this reason, the aim of the paper was to confirm the importance of the brand in consumer buying decisions and to find out whether consumers really perceive the brand as a guarantee of product quality. To meet the aim of the paper, we conducted a questionnaire survey, which confirmed the importance of the brand in consumer purchasing decisions and the perception of the brand as a guarantee of product quality. We also confirmed a statistically significant dependence between brand perception as a guarantee of product quality and the age of respondents, confirming the importance of demographic characteristics in the implementation of company marketing activities.
\end{abstract}

JEL Classification Numbers: M37, DOI: 10.12955/cbup.v7.1382

Keywords: Brand, Product, Quality

\section{Introduction}

Consumers are influenced by many factors in their purchasing decisions, be it their economic situation, expectations, the influence of the environment in which they live, the lifestyle they prefer, or preferences from their surroundings. One of the factors that influence consumer purchasing decisions is also the brand of the product. For consumers, the brand is of great importance today as there are many different manufacturers in the market and one or more brands are associated with each manufacturer (Valaskova et al., 2018). The goal of a company is therefore to create a brand that will be successful on the market. To achieve that goal, they must use an effective combination of marketing tools to create a strong awareness of their brand (Moravcikova et al., 2017).

In today's marketplace, companies often have a difficult role in creating new brands, or in strengthening their existing brands. This is because on the market today, there is an incredibly large number of small, medium or large companies with which they are competing for loyal customers (Szkutnik \& Szkutnik, 2018). The creation of a strong brand is therefore becoming one of the most important marketing activities of any company operating in all producer's sectors (Alshehhi \& Olah, 2017). The essence of a strong brand is to provide the information the consumer is looking for before competing companies can (Cygler \& Sroka, 2017). Its role is to make it easier for consumers to choose products. That is why companies are trying to create product associations so that consumers perceive it as a quality product and as a product that always meets their expectations. Consequently, building a brand with tradition is a way of achieving consumer loyalty so that consumers will not have to doubt the quality of that brand.

\section{Theoretical background}

The brand is seen by consumers as an important part of the product as it contributes to its value. Companies are therefore trying to create brands that bring positive mental associations to consumers. The purpose, direction and meaning are given by brand identity. Identity involves a unique array of associations that business and marketing departments try to maintain and derive, whose job is to build a customer-producer relationship. The manufacturer is committed to the customer that their product is of adequate quality (Massey et al., 2018). If consumers are convinced of the quality of the brand's products, there is a high probability that they will become loyal consumers of the brand, contributing to building and increasing brand value (Kliestikova \& Janoskova, 2017). Therefore, it is essential to focus on strengthening brand value because it brings competitive advantages to the brand owner and also derives from many benefits, such as perception of brand quality, customer loyalty, and so on (Radulescu \&

\footnotetext{
${ }^{1}$ University of Zilina, Faculty of Operation and Economics of Transport and Communications, Department of Economics, Zilina, Slovak Republic, viera.valjaskova@fpedas.uniza.sk

${ }^{2}$ University of Zilina, Faculty of Operation and Economics of Transport and Communications, Department of Economics, Zilina, Slovak Republic, pavol.kral@fpedas.uniza.sk
} 
Hudea, 2018). Therefore, companies should strive to keep their brand value for a long time and acquire new customers, because they cannot only maintain their value but also increase their value.

Brands can be classified into several groups based on the value and degree of market recognition. The strongest brands are brands that have a high degree of loyalty from consumers. They are followed by brands that are significantly preferred to others. Brands that have a high level of acceptance mean that consumers like to buy them. Furthermore, there are brands that consumers recognize, search for, so they have a good knowledge of the brand. Finally, there are brands that are not known to consumers, so consumers do not have a good knowledge of them, they do not search for them, nor do they recognize them amongst other brands (Aaker, 2003).

In connection with the brand's reputation in the minds of customers, it is essential to select marketing communication tools that will introduce the brand and make it known to a large number of potential customers. Nowadays, in which social media and online marketing has a large impact on consumer decision-making, companies use this tool to communicate with customers (Lăzăroiu, 2018). Hsu (2019) therefore explored the impact of brokerage relationships between community members and the brand and created a model that determines the impact of these factors on customer buying behavior. Among other things, he found that brand trust and brand passion played an important brokerage role. Kaspar et al. (2019) also paid attention to online marketing, specifically examining the impact of demographic targeting of ads on brand rating and visual customer attention. The results of a study by Bacik et al. (2018) promote the importance of using social media, as the fastest tool to communicate with customers, for branding purposes, as they have the greatest impact on consumer perception and attitudes. Stefko et al. (2016) discussed the impact of website content on the image of educational institutions.

Kim \& Sullivan (2019) argue that brand technical parameters such as product attributes, product features may be infallible, but personal feelings and experiences better shape brand evaluation from a consumer perspective. Ugalde et al. (2019) investigate whether brand awareness or brand credibility is needed to develop brand identification that affects consumer purchasing decisions. They found that brand credibility has a greater impact on brand identification than brand awareness. It is therefore necessary for companies to focus their attention on ensuring that consumers perceive their brands as trustworthy and do not doubt their quality. Lin \& Chuang (2018) explored the relationship between brand image, customer attitude, intent and loyalty, and found, based on a questionnaire survey, that brand image affects consumers' attitudes and purchasing intentions. Nobar \& Rostamzadeh (2018) found that consumer satisfaction, experience and loyalty have an impact on brand strength in the hotel industry.

\section{Methods}

Given the facts outlined in the previous section of this paper, we wanted to find out what the brand's real importance is in a buying customer's behavior, and whether customers assess the quality of purchased products by product brand. For the purpose of fulfilling the aim of our paper, we used a questionnaire as a tool that we distributed through social networks. We chose social networks precisely because of their growing importance in company communications with customers, and because more and more people are active on social networks, allowing us to get the necessary sample size ( 384 respondents) faster than using another contact method.

We focused our research on a specific kind of product, namely mobile phones. The reason for focusing the research on these products was the ever-increasing attractiveness of the telephony industry and the fact that nowadays mobile phones have become an important part of human life. Among other things, mobile phone brands will be ranked among the top 100 most valuable brands in the world each year, and the top three brands of mobile phone brands in 2018 were Samsung, Apple and Huawei (Brandz ${ }^{\mathrm{TM}}$, 2018).

Of the total number of respondents, $223(58 \%)$ were women and $161(42 \%)$ were men. The largest share of the sample was reported by respondents aged 21-30, who represented 279 respondents with 73 $\%$ of the total sample of respondents. The share corresponds to the largest users of social networks, especially young people. According to the amount of net monthly income, 134 respondents (35\%) had up to $300 €, 165$ respondents $(43 \%)$ had $301 €-600 €, 61$ respondents $(16 \%)$ had $601 €-1000 €$ and 24 respondents $(6 \%)$ had more than $1,000 €$. The three most frequently owned brands of mobile phones were Samsung, owned by 130 respondents ( $34 \%$ ), followed by Huawei, owned by 83 respondents ( 22 $\%)$ and then Apple, owned by 90 respondents (23\%). In terms of brand awareness, we were wondering 
which three brands attracted the respondents first, with the three most repeating brands being Apple (288, $75 \%)$, Samsung $(175,46 \%)$ and LG (170, $44 \%)$.

\section{Results and Discussion}

The main aim of our paper was to find out the importance of the brand in purchasing decisions of customers and whether the brand has an impact on the perception of product quality. In addition, we wanted to find out whether the demographic characteristics of respondents have an impact on brand perception as an attribute that expresses product quality. For the purpose of fulfilling the main aim of the paper, we have set the following research questions, which we have answered from the answers to the specific questions of the questionnaire survey.

Research question 1: Which criteria are important when deciding on buying a mobile phone?

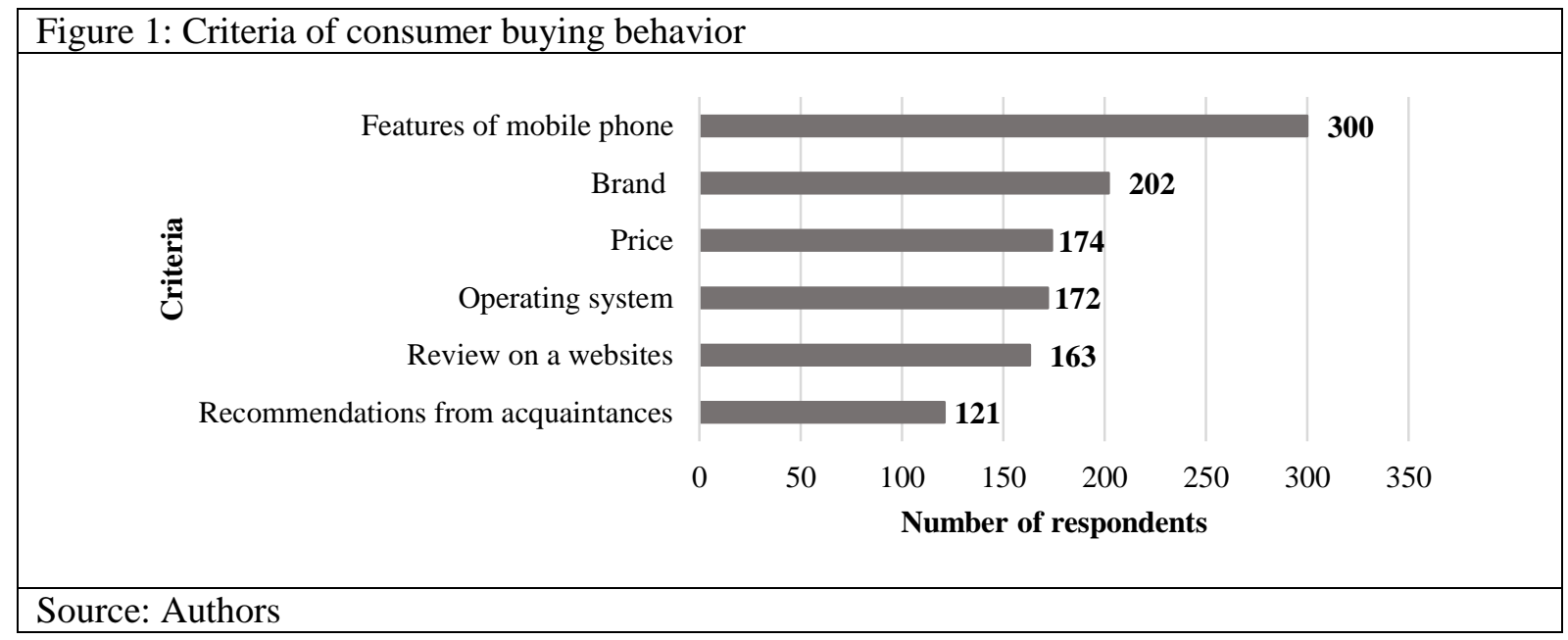

From the answers of the questionnaire: "By what criteria do you decide to buy a mobile phone?" we can see that most of the respondents $(300,78 \%)$ mentioned the most important criterion when deciding to buy a mobile phone are the features of mobile phones. In the second place, the already mentioned brand, with 202 responses (53\%), while 174 respondents placed the greatest emphasis on price (45\%), mobile operating system $(172,45 \%)$, website reviews $(163,42 \%)$ and, finally, recommendations from friends $(121,32 \%)$.

Research question 2: Is the brand of mobile phone perceived as a guarantee of quality?

\begin{tabular}{|l|}
\hline Figure 2: The brand as an indicator of product quality \\
\hline Gives Gino \\
\hline Source: Authors
\end{tabular}

As can be seen in Figure 2, most respondents $(210,55 \%)$ see the brand as a product quality indicator, and 174 respondents $(45 \%)$ do not share the opinion that the brand is a guarantee of mobile phone quality.

Based on the theoretical background chapter, where research results confirm the importance of demographic characteristics in brand evaluation, we wanted to determine whether there is a statistically significant relationship between the brand as a quality indicator and gender and also the age of respondents. 
First, we verify the hypothesis: Is there a statistically significant relationship between the brand as a quality indicator and the gender of the respondents? We implemented the Chi-Square test using the SPSS software, as both characters were nominal variables. We set the test hypotheses:

H0: The brand as a quality indicator and gender is independent.

H1: The brand as a quality indicator and gender are dependent.

We verified the hypothesis on the significance level alfa $=0.05$ with which we compared the resulting p-value. P-value $0.170>0.05$, that means, we do not reject the null hypothesis. We have found that there is no statistically significant relationship between the brand as a quality indicator and gender.

\begin{tabular}{|c|c|c|c|c|c|}
\hline & Value & df & $\begin{array}{c}\text { Asymptotic Significance (2- } \\
\text { sided) }\end{array}$ & \begin{tabular}{|c|}
$\begin{array}{c}\text { Exact Sig. (2- } \\
\text { sided) }\end{array}$ \\
\end{tabular} & $\begin{array}{l}\text { Exact Sig. (1- } \\
\text { sided) }\end{array}$ \\
\hline Pearson Chi-Square & 1.883 & 1 & 0.170 & \multirow{6}{*}{0.179} & \multirow{6}{*}{0.102} \\
\hline Continuity Correction & 1.609 & 1 & 0.205 & & \\
\hline Likelihood Ratio & 1.882 & 1 & 0.170 & & \\
\hline Fisher's Exact Test & & & & & \\
\hline Linear-by-Linear Association & 1.878 & 1 & 0.171 & & \\
\hline $\mathbf{N}$ of Valid Cases & 384 & & & & \\
\hline
\end{tabular}

Source: Author

Subsequently, we verified the hypothesis: Is there a statistically significant relationship between the brand as a quality indicator and the age of respondents? We set the test hypotheses:

H0: The brand as a quality indicator and age is independent.

H1: The brand as a quality indicator and age are dependent.

We verified the hypothesis on the significance level alfa $=0.05$ with which we compared the resulting p-value. P-value $0.01<0.05$, meaning we reject the null hypothesis and accept the alternative hypothesis. We have found that there is statistically significant relationship between the brand as a quality indicator and age.

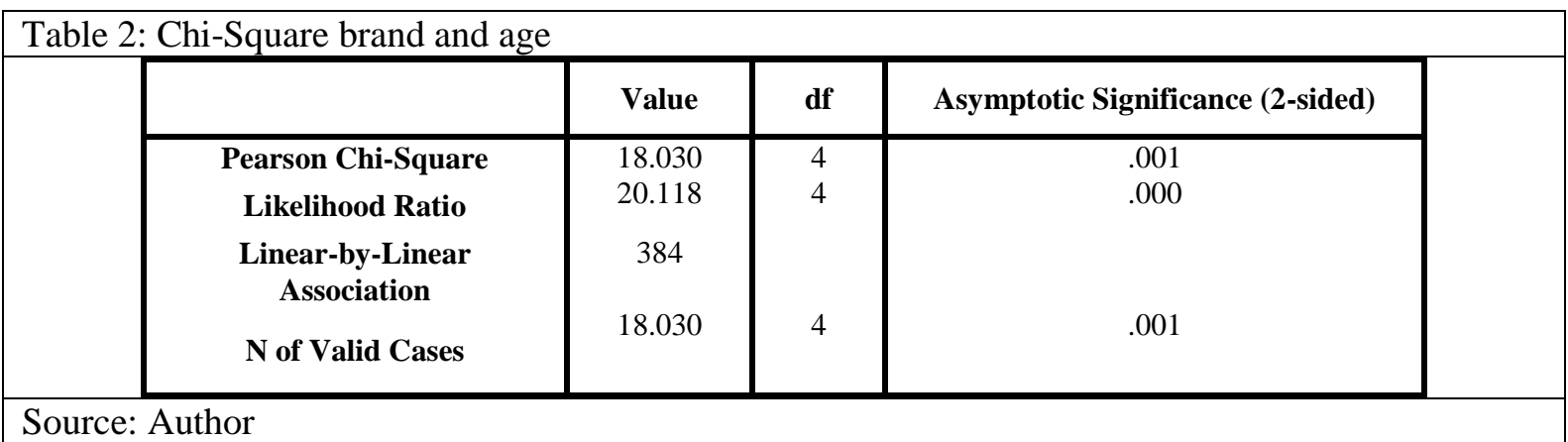

We proceeded to calculate the intensity of dependence, and we found out that there is a moderate dependency between the brand as a quality indicator and age, as Cramer's V is 0.217 and the Contingency Coefficient is 0.212 .

Table 3: Contingency coefficients

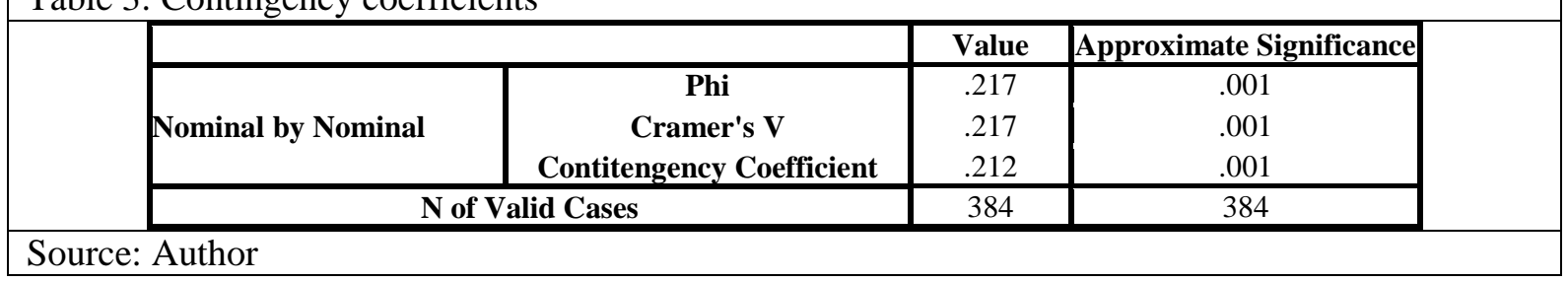

\section{Conclusion}

The main aim of our paper was to determine the importance of the brand when consumers decide to buy a product, namely to buy mobile phones, and to find out whether respondents perceive the brand as an indicator of the quality of mobile phones. The results of the questionnaire survey confirmed that the 
brand is the second most important criterion right after the features of the mobile phones when deciding to buy mobile phones. Most respondents also regard the brand as a quality indicator for mobile phones. For this reason, and because of the importance of demographic characteristics in the implementation of marketing activities as such, we have decided to verify two hypotheses to see if there is a statistically significant relationship between the brand as a quality indicator and the demographic characteristics of respondents (gender and age). We found out that a statistically significant (moderate) relationship exists only between the brand as a quality indicator and age.

\section{Acknowledgement}

This paper is an outcome of project APVV-15-0505: Integrated model of management support for building and managing the brand value in the specific conditions of the Slovak Republic.

\section{References}

Aaker, D. (2003). Brand building: budování obchodní značky. Brno: Computer Press.

Alshehhi, Y.Z., \& Olah, J. (2017). Sectorial analysis: Growth accounting of secondary industries. Network Intelligence Studies, 5(9), 39-45.

Bacik, R., Fedorko, R., Nastisin, L., \& Gavurova, B. (2018). Factors of communication mix on social media and their role in forming customer experience and brand image. Management \& Marketing-Challenges for the Knowledge Society, 13(3), 1108-1118.

Cygler, J, \& Sroka, W. (2017). Coopetition disadvantages: the case of the high-tech companies. Inzinerine EkonomikaEngineering Economics, 28(5), 494-504.

Global Top 100 Brands 2018 (2018). Retrieved from http://brandz.com/charting/54

Hsu, L. C. (2019). Building Brand-Fan Relationships in Social Commerce Contexts: Mediators of Online Brand Relationships. Journal of Theoretical and Applied Electronic Commerce Research, 14(2), 106-123.

Kaspar, K., Weber, S. L., \& Wilbers, A. K. (2019). Personally relevant online advertisements: Effects of demographic targeting on visual attention and brand evaluation. PLoS ONE, 14(2), 1-18.

Kim, Y. K., \& Sullivan, P. (2019). Emotional branding speaks to consumers' heart: the case of fashion brands. Fashion and Textiles, 6(2), 1-16.

Kliestikova, J., \& Janoskova, K. (2017). Branding with understanding: how national profile of consumer influences brand value perception. Marketing and Management of Innovations, (3), 149-157.

Lăzăroiu, G. (2018). Participation environments, collective identities, and online political behavior: the role of media technologies for social protest campaigns. Geopolitics, History, and International Relations, 10(2), 58-63.

Lin, C. T. L., \& Chuang, S. S. (2018). The importance of brand image on consumer purchase attitude: a case study of e-commerce in Taiwan. Studies in Business and Economics, 13(3), 91-104.

Massey, G., Kliestikova, J., Kovacova, M., \& Dengov, V. V. (2018). The perceived accuracy of fake news: mechanisms facilitating the spread of alternative truths, the crisis of informational objectivity, and the decline of trust in journalistic narratives. Geopolitics, History, and International Relations, 10(2), 37-43.

Moravcikova, D., Krizanova, A., Kliestikova, A., \& Rypakova, M. (2017). Green marketing as the source of the competitive advantage of the business. Sustainability, 9(12), art. no. 2218.

Nobar, H. B. K., \& Rostamzadeh, R. (2018). The impact of customer satisfaction, customer experience and customer loyalty on brand power: empirical evidence from hotel industry. Journal of Business Economics and Management, 19(2), 417-430.

Radulescu, C., \& Hudea, O. S. (2018). Econometric modelling of the consumer's behaviour in order to develop brand management policies. Economic Research-Ekonomska Istrazivanja, 31(1), 576-591.

Stefko, R., Fedorko, R., \& Bacik, R. (2016). Website content quality in terms of perceived image of higher education institution. Polish Journal of Management Studies, 13(2), 153-163.

Szkutnik W., \& Szkutnik W. (2018). Socio-economic convergence in models of endogeneous economic growth. Ekonomicko-manazerske Spektrum, 12(2), 1-14.

Ugalde, C., Lopez, N. V., Boluda, I. K., \& Mora, E. (2019). Brand awareness and brand credibility leading to brand identification. Obra Digital-Revista de Comunicacion, (16), 63-76.

Valaskova, K., Kliestikova, J., \& Krizanova, A. (2018). Consumer perception of private label products: an empirical research. Journal of Competitiveness, 10(3), 149-163. 